Brit. J. vener. Dis. (1964), 40, 146.

\title{
TREATMENT OF NON-GONOCOCCAL URETHRITIS WITH
}

\section{5-IODO-2'-DEOXYURIDINE*}

\author{
BY \\ DAVID C. HUTFIELD $†$ \\ St. Mary's Hospital, London
}

5-iodo-2'-deoxyuridine (5IDU) is an antiviral compound which has a chemical composition closely resembling that of thymidine; the antiviral effect is thought to be due to the metabolic antagonism to the uptake of thymidine in the deoxyribonucleic acid (DNA) molecule (Prusoff, 1959). This molecule combined with protein is the main composition of the herpes simplex virus, upon the metabolism of which the effects of this drug have so far been mainly studied. The similarity in the molecular configuration of thymidine and 5-iodo-2'-deoxyuridine is shown in the Figure.
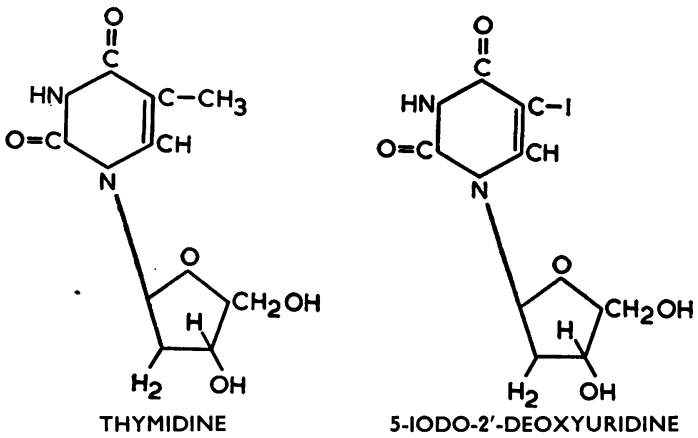

The effect of 5IDU as an inhibitor of herpes simplex and vaccinial viruses in tissue culture was first reported by Herrmann (1961). Kaufman, Nesburn, and Maloney (1962), however, first demonstrated its favourable clinical effects in the treatment of herpetic keratitis in rabbits, and later confirmed this observation in human beings. Corrigan, Gilkes, and Roberts (1962) reported equally good results in fifteen patients with dendritic ulceration. A favourable clinical response of herpes simplex skin infections to 5IDU was recorded by Hall-Smith, Corrigan, and Gilkes (1962). These published reports appear to substantiate the clinical effectiveness of 5IDU in herpes simplex infections and suggest its trial in other possible viral infections.

* Received for publication August 12, 1963

† Now at the Whitechapel Clinic, The London Hospital, E.1.
In the majority of cases the aetiology of nongonococcal urethritis (NGU) is unknown, but inclusion bodies of a virus have been found in the urethral epithelial cells in some cases. Siboulet (1955) and Siboulet and Galistin (1962) quote an incidence of 3 per cent. in 2,756 cases and also demonstrated inclusion bodies in malformed chickembryos obtained by inoculation of urethral material from three patients with Reiter's disease. Whittington (1962), however, was unable to isolate a virus on egg inoculation in twenty cases of NGU, which included one case of Reiter's disease. The assumption of a possible virus aetiology of NGU prompted this investigation with 5IDU, although similar investigations with other antiviral compounds by Lloyd-Davies (1962) and by Duncan and Morton (1962) have proved to be ineffective in the treatment of this disease. Treatment with oxytetracycline, which has antibacterial and antiviral effects against large viruses, has met with a success rate of 85 per cent.

\section{Case Material and Management}

25 men with NGU were used initially in this trial but five defaulted within 5 days and had to be excluded. The remaining twenty included fourteen new acute oases which had had no previous treatment, four chronic cases which had been previously treated without benefit with oxytetracycline, streptomycin, and sulphonamides, or with urethral irrigations of oxycyanide of mercury, and two cases in which NGU followed an attack of gonorrhoea. Their average age was 27.7 years (range 18 to 36 ), twelve were coloured, and eight were white. There was a history of previous attacks of NGU in three cases and of previous attacks of gonorrhoea in six, but the remainder had suffered no previous venereal incident.

Urethral smears and saline suspension preparations were examined in all patients to exclude gonococci and Trichomonas vaginalis respectively. Serological tests for syphilis were also carried out at the same time.

These tests were negative in all cases, and a diagnosis of NGU having thus been established, the patient was instructed to pass urine so as to empty the bladder completely before the first instillation of 5IDU into the urethra. The urine specimen findings were also recorded in the usual way, and all cases contained threads. SIDU 
was supplied as a 0.5 per cent. ointment contained in a $5 \mathrm{~g}$. tube, the nozzle of which was inserted into the urethral meatus and firmly held whilst a small amount was squeezed into the anterior urethra and then massaged back into the posterior urethra as far as possible. The tube was then removed and the patient instructed not to pass urine for 3 hours, so as to allow maximum contact between the ointment and the urethral mucosa. Instructions were then given to repeat this procedure four times daily, ensuring that the final application was made last thing at night before retiring, so that a high concentration of the drug was maintained. Each tube of ointment used in this way would last about 5 days and the patient had to return on the fifth day for a repeat urethral smear and urine test. A follow up for 3 months was planned. Primary defaulters were not included because a second urethral smear examination after treatment with 5IDU was considered essential in determining the effects of this drug.

\section{Results}

The pus which had been present in the first urethral smear (epithelial cells only) disappeared over the 5-day period of treatment with 5IDU in nine out of the twenty cases ( 45 per cent.). This resulted in a complete cessation of the discharge and a clear urine specimen in three cases (15 per cent.), but relapse occurred in six cases ( 30 per cent.). This gives an overall cure rate of 15 per cent. for 5IDU in the treatment of NGU.

It was noted that, of the three cases showing complete remission, one was a new case in which the discharge had been present for only 3 days, another had NGU following an attack of gonorrhoea, and the third was a chronic case which had relapsed for one month on previous treatment.

\section{Discussion}

These results indicate that 5IDU in its present form is unsuitable in the treatment of NGU, as a minimum of 50 per cent. of cases will improve with placebo therapy alone, and Gartman and Leibovitz (1955) have shown that three out of five cases of NGU will subside spontaneously in 8 weeks.

The low cure rate of 15 per cent. with 5IDU may be due to several factors:

(1) Most cases of NGU are not due to a virus, since figures of only 3 per cent. have been quoted.

(2) 5IDU may not affect the particular virus that may possibly cause NGU.

(3) The high failure rate may be due to bad technique in applying this preparation to the site of infection; it will be appreciated that there is considerable difficulty in massaging an ointment from the anterior to the posterior urethra, and in some cases it is doubtful whether the posterior urethra was exposed to its action at all. This may well have been the reason for a relapse in the six cases in which there was an initial change in the urethral smear findings, since the anterior urethra may have been cleared of infection but later re-infected by the untreated posterior urethra. This theory cannot be proved, but the fact that the urethral smear became free of pus in 45 per cent. of cases led to a suggestion to the manufacturers that 51DU might be given in another form, parenterally or by urethral irrigation, thus ensuring a thorough treatment of the posterior urethra. Unfortunately, it is not possible to give 5IDU parenterally, and a solution for urethral irrigation is considered impracticable because of its high cost.

\section{Summary}

A trial of 5-iodo-2'-deoxyuridine (5IDU) in twenty cases of non-gonococcal urethritis (NGU) is described. It is concluded that this compound with proven antiviral properties is unsuitable in its present form for the treatment of NGU.

I am indebted to Dr F. J. G. Jefferiss and Dr R. R. Willcox for permission to include their patients in this study, to Dr G. W. Csonka for criticism and advice in the final preparation of the script, and to Dr Johnston of Messrs Smith, Kline and French Ltd. for the supply of SIDU.

\section{REFERENCES}

Corrigan, M. J., Gilkes, M. J., and St. Clair Roberts, D. (1962). Brit. med. J., 2, 304.

Duncan, W. A. M., and Morton, R. S. (1962). Brit. J. vener. Dis., 38, 64.

Gartman, E., and Leibovitz, A. (1955). Ibid., 31, 92.

Hall-Smith, S. P., Corrigan, M. J., and Gilkes, M. J. (1962). Brit. med. J., 2, 1515.

Herrmann, E. C. (1961). Proc. Soc. exp. Biol. (N.Y.) 107,142 .

Kaufman, H. E., Nesburn, A. B., and Maloney, E. D. (1962). Arch. Ophthal. (Chicago), 67, 583.

Lloyd-Davies, R. W. (1962). Brit. J. vener. Dis., 38, 69.

Prusoff, W. H. (1959). Biochim. biophys. Acta, 32, 295.

Siboulet, A. (1955). Brit. J. vener. Dis., 31, 235

- and Galistin, P. (1962). Ibid., 38, 209.

Whittington, M. J. (1962). Ibid., 38, 200.

\section{Traitement de l'urétrite non-gonococcique par 5-iodo-2'-desoxyuridine (5 IDU)}

\section{RÉSUMÉ}

On décrit une série de 20 cas d'urétrite non-gonococcique traités par 5 IDU. Ce médicament n'eut aucun effet sur l'urétrite non-gonococcique malgré son pouvoir attesté contre les virus. 